\title{
Stanisław Staszic - ostatnia przestroga dla Polski
}

\author{
Boris Nosow
}




\section{Boris Nosow}

\section{Stanisław Staszic - ostatnia przestroga dla Polski}

$\mathrm{P}$ rzełom XVIII i XIX wieku, epoka Wielkiej Rewolucji Francuskiej i wojen napoleońskich, wraz z następującym po nim okresem restauracji gruntownie zmieniły oblicze Europy, a nawet całego świata, kiedy to rozpoczął się przewrót nie tylko w stosunkach społecznych, lecz także w sferze całej świadomości społecznej. Wszystko to w równej mierze, jeśli nie w najwyższym stopniu, przejawiło się we wzajemnych kontaktach Rosji i Polski, co oczywiście musiało odbić się na wzajemnym postrzeganiu się naszych narodów.

Rzecz jasna, nie można $\mathrm{w}$ granicach poniższego tekstu, nawet $\mathrm{w}$ przybliżeniu, zbadać wszystkich najważniejszych tendencji w ewolucji wzajemnych wyobrażeń o sobie Polaków i Rosjan w omawianym okresie, którego ramy chronologiczne stanowią daty 1788 i 1830, zakreślające czas od rozpoczęcia Sejmu Wielkiego w Warszawie do wybuchu polskiego powstania 1831 r. Prócz tego należy zaznaczyć, iż wspomnianego problemu w odniesieniu do epoki rozbiorów Polski dotknęliśmy już w maju 1998 r. we wspólnym referacie z G. W. Makarową Rosja i powstanie Tadeusza Kościuszki: wyobrażenia o Polsce $w$ kreggach rzq̨dzqcych Imperium Rosyjskiego w XVIII wieku ${ }^{1}$.

Dlatego też w obecnym referacie odważyliśmy się zająć jedynie twórczością wybitnego polskiego myśliciela i działacza społecznego i politycznego epoki Oświecenia, Stanisława Staszica (1755-1826) ${ }^{2}$, mając oczywiście na myśli nie tyle analizę jego dzieł i poglądów

' Zob. G. W. Makarowa, B. W. Nosow, Rosja i powstanie Tadeusza Kościuszki: wyobrażenia o Polsce $w$ kregach rzadzacych Imperium Rosyjskiego $w$ XVIII wieku (Polska - Rosja. Rola polskich powstań narodowych $w$ ksztattowaniu wzajemnych wyobrażeń. Konferencja naukowa, 14-15 maja 1998 r., Warszawa, Instytut Historii PAN, 1998).

${ }^{2}$ Ważniejsze publikacje dziel Stanisława Staszica, oprócz prac wydanych za życia pisarza: Pisma filozoficzne i spoleczne, opr. i wst. B. Suchodolski, t. 1-2, Kraków 1954; Ród ludzki. Wersja brulionowa, opr. Z. Daszkowski, wst. B. Suchodolski, Warszawa 1959; Uwagi nad życiem Jana Zamoyskiego, opr. S. Czarnowski, przyg. do dr. B. Leśnodorski, Wrocław 1952 (BN I 90). 
spoleczno-politycznych, lecz to, w jaki sposób na kartach jego prac znalazły odbicie główne sprzeczności epoki, oglądane przez pryzmat wzajemnych stosunków Polaków i Rosjan.

Droga twórcza Stanisława Staszica jako działacza i filozofa epoki Oświecenia w pewnym sensie stanowi unikalne zjawisko w historii europejskiej myśli społecznej. Ideologia Wieku Oświecenia na zachodzie Europy zakończyła swoje istnienie w czasie Rewolucji Francuskiej. $\mathrm{Na}$ wschodzie kontynentu zachowała ona swój wpływ i znaczenie o wiele dłużej, aż do końca lat dwudziestych XIX wieku. Zarazem w krajach Europy środkowej i wschodniej przedstawiciele myśli oświeceniowej minionego wieku nie wkroczyli jako twórcy w nowe stulecie, jakby ustępując miejsca ideologom Oświecenia nowego wieku. Na tym tle Stanisław Staszic stanowi nadzwyczaj ważny wyjątek. Był on jednym z czołowych przedstawicieli myśli społecznej Rzeczypospolitej epoki Sejmu Czteroletniego, a po zakończeniu wojen napoleońskich jego rola społeczna i polityczna w Polsce nie tylko nie uległa osłabieniu, lecz istotnie wzrosła, ponieważ dokładnie na ostatni okres twórczej pracy Staszica przypadają najbardziej znaczące jego dzieła, które wywarły największy wpływ na rozwój polskiej świadomości narodowej. Ciągłość rozwoju oświeceniowych idei Staszica można byłoby zilustrować choćby tym, iż jego Przestrogi dla Polski, wydane po raz pierwszy 4 stycznia 1790 r., w 1816 r. zostały umieszczone przez autora w dziełach zebranych razem z Uwagami nad życiem Jana Zamoyskiego. Co prawda, w porównaniu $\mathrm{z}$ wydaniem z $1790 \mathrm{r}$., z tekstu wyeliminowano bezpośrednie wzmianki o Rosji. Należy przy tym podkreślić, że nowa publikacja Przestróg nie oznaczała wyłącznie daniny złożonej twórczej przeszłości autora i bynajmniej nie była jej przeznaczona zaszczytna, lecz mało znacząca rola jednego $z$ literackich pomników minionego czasu. Programowe dzieło polskiego myśliciela zachowało swoją aktualność także w nowych społeczno-politycznych warunkach Królestwa Polskiego po Kongresie Wiedeńskim.

W 1816 r. Staszic powtórzył swoje przekonania sprzed 25 lat o tym, iż „w Polsce jeszcze oligarchia szlachecka. Polska dopiero w wieku piętnastym. Cała Europa już wiek osiemnasty kończy" ${ }^{3}$. Według jego słów, wyrwać się z poniżającego położenia, zrzucić z siebie cudzoziemskie jarzmo (w pierwszym wydaniu mówi się o jarzmie „samodzierżycy Rusów”) Polacy będą mogli tylko w tym wypadku, gdy przetworzą Polskę tak, aby mogła ona "stanąc w rzędzie Europy”. Dla osiągnięcia tego celu, pisał Staszic, „trzeba oddać całą ziemię staranności i pracy wszystkich Polaków, trzeba powrócić rolnikowi sprawiedliwość, trzeba zapewnić rzemieślnikom i kupcom bezpieczeństwo i wolność, trzeba miasta przypuścić do towarzystwa, zgoła połączyć, zjednoczyć wszystkich Polaków (...)" .

Kształtowanie nowych wyobrażeń o wolności ludu i o narodzie jako takim, u których źródeł stał Stanisław Staszic, ogłaszając naród twórcą i obrońcą ojczyzny, a nie po prostu przedmiotem rządów, i w Polsce, i w Rosji związane było ze stopniowym wyzwalaniem się opinii powszechnej z oków przesądów stanowych i politycznych. Najważniejszym przeło-

${ }^{3}$ S. Staszic, Pisma filozoficzne..., t.1, s. 303.

${ }^{4}$ Ibid., s. 308-309. 
mem na tej długiej i pełnej przeciwności drodze stała się świadomość, iż ludy same tworzą swoje historyczne przeznaczenie, same określają własne ideały etyczne i estetyczne. W literaturze badanego tu okresu tendencje takie, naszym zdaniem, najjaskrawiej wystąpiły w twórczości Adama Mickiewicza, Seweryna Goszczyńskiego (Zamek kaniowski) i Aleksandra Puszkina. Znamienne, że w twórczości wymienionych autorów po raz pierwszy w artystycznym obrazowaniu wyraziło się nie tylko przeciwstawienie Rosji i Polski, nie tylko ich polityczny antagonizm, który w rezultacie doprowadził do upadku Rzeczypospolitej, lecz także dążenie do zarysowania w portretach bohaterów (z jednej strony Polaków, z drugiej Rosjan) cech pozytywnych, według powszechnych wyobrażeń odpowiadających rdzennemu charakterowi obu nacji. Potępione zostały natomiast stanowa pycha i egoizm. Jeśli literatura tamtego okresu mówi o Polakach i Rosjanach, przekazuje przede wszystkim obrazy godnych przeciwników, a bezwzględnie potępia jedynie nikczemność i zaprzedanie. Takie podejście w znacznym stopniu było podyktowane, rzecz jasna, kanonami romantyzmu, ale bez wątpienia sprzyjało tworzeniu atmosfery wzajemnego szacunku.

Mówiąc o oświeceniowej koncepcji narodu u Staszica, nie sposób pominąć jej pierwszorzędnej cechy, odgrywającej, według nas, bardzo ważną rolę w kształtowaniu wzajemnego postrzegania się narodów, w tej liczbie także Polaków i Rosjan. Zgodnie z poglądami oświeconych, wszyscy ludzie mają taką samą wewnętrzną naturę i są równi wedle praw przyrody. Teza taka, zakładająca odrzucenie niesprawiedliwości stanowej, wiązała się jednak ze sprzecznością między wyobrażeniem o jednorodnej, oświeconej wspólnocie wszystkich ludzi a coraz wyraźniejszą narodową tożsamością ludów. Teoretyczne rozwiązanie tej sprzeczności u Staszica leżało w granicach możliwego, jego zdaniem, bezkonfliktowego rozwoju narodów w warunkach wolności. Oznaczało to $z$ jednej strony przezwyciężenie staroszlacheckich wyobrażeń o stanowej i narodowej odrębności Polaków, a z drugiej - odrzucenie mocarstwowego prawa Rosji i innych potencji do rozporządzania losem Europy i Polski. W ten sposób w dziełach Staszica (Ród ludzki) powszechne starania ludzi o wolność przeciwstawiały się nieprzychylnym okolicznościom politycznym, co prowadziło zwłaszcza do wnioskowania o ogólnie słusznym dążeniu Polaków i Rosjan do wolności, a w efekcie budowało korzystną podstawę dla wzajemnego pozytywnego postrzegania się przez nasze narody.

Zgodnie z fundamentalnymi założeniami teorii „umowy społecznej”, obowiązek zrealizowania właściwych oczekiwań narodu - otworzenia mu drogi ku oświeceniu i wolności — spoczywał na władzy monarszej. W tym też duchu zwraca się do polskiego króla Staszic, wykładając swój program w 36 rozdziale Przestróg, zatytułowanym przez niego Wniosek dla Polski.

Warto zaznaczyć, że w tym czasie analogiczne idee wypowiadali oświeceni także w Rosji. Wskażmy przede wszystkim niezwykle ważne stanowisko, wyrażone w ustawie Związku Ocalenia (1818), gdzie była mowa o tym, iż przyszli dekabryści zamierzali „wspierać rząd” w podnoszeniu Rosji na nowy stopień historycznej wielkości. Treść tego twierdzenia staje się zrozumiała, jeśli uwzględnić, że w ramach tradycyjnych wyobrażeń o politycznej potędze w tym właśnie okresie imperium Aleksandra I dosięgło ostatecznych możliwych do pomy- 
ślenia granic. W rezultacie można było mówić jedynie o wprowadzeniu swobód powszechnych, co rzeczywiście znajdowało potwierdzenie także w innych programowych dokumentach Związku (Zielona ksiega).

Zwracając się powtórnie do polskiego władcy w 1816 roku, Staszic mial tym razem na myśli rosyjskiego imperatora, który ogłosił się polskim królem i został zatwierdzony jako taki przez polski Sejm i konstytucję. Nie podejmujemy się dociekać, czy w tym wypadku miał na względzie konkretnie cara Aleksandra, czy prawdziwego oświeconego monarchę — filozofa na tronie w ogóle. Jednak bez wątpienia to właśnie na rosyjskim władcy Staszic opierał swe nadzieje, kiedy pisał:

Polacy są nieudolni być waszymi niewolnikami, ale są przygotowani stać się waszymi braćmi. Połączcież ten naród $z$ właściwą mu ustawą narodowego prawa i rządu pod jednym cesarzem i królem w wielką rzeszę Cesarstwa ${ }^{5}$.

Przytoczone wyżej słowa Staszica pochodzą z jego wykładu zatytułowanego Mysli o równowadze politycznej $w$ Europie, wygłoszonego w Warszawie w sierpniu $1815 \mathrm{r}$. Zatrzymamy się tylko nad poszczególnymi jego tezami. Po pierwsze, Staszic poddaje w nim krytyce podstawową zasadę polityki europejskiej XVIII i XIX wieku — „systemat równowagi”. Stwierdza, że poczynając od 1772 r. Polska wzywała pomocy i nie została usłyszana, że w europejskiej polityce „nic w równowadze stałego nie ma i nie było"6. Po drugie, według zdania filozofa, „systemat równowagi” i reguła starego porządku stanęły w sprzeczności na przełomie XVIII i XIX stulecia, o czym świadczyły postanowienia Kongresu Wiedeńskiego. Pojęcia „dawnego systematu" Staszic używał nie w tradycyjnym dla nas sensie ancien régime'u, lecz w znaczeniu odwiecznego prawa narodów („dawny systemat niepodległości i całości już ustanowionych krajów" ${ }^{77}$, wolnego od wiekowej despotycznej przemocy, której jaskrawym przykładem była dla filozofa zwłaszcza epoka wojen napoleońskich. Po trzecie, drogę wyzwolenia z międzynarodowej samowoli Staszic upatrywał w utworzeniu związku narodów słowiańskich.

W ten sposób koncepcja stosunków międzynarodowych, rozwinięta przez Staszica, nie tylko znajdowała się na poziomie najbardziej postępowych politycznych teorii swego okresu, lecz także, co istotne, była nierozerwalnie związana z odrzuceniem idei Świętego Przymierza. $\mathrm{Z}$ tego punktu widzenia wyobrażenie Staszica o związku polsko-rosyjskim odpowiadało zapatrywaniom liberalnych i rewolucyjnych odłamów myśli społecznej Rosji i Polski odłamów, które w czasach Staszica (do 1825 r.) nie odseparowały się jeszcze w zupełności. Takie podobieństwo poglądów nie mogło $z$ kolei nie wpłynąć pozytywnie na tworzenie wzajemnych wyobrażeń o sobie przez nasze narody.

${ }^{5}$ Ibid., t.2, s. 318-319.

${ }^{6}$ Ibid., s. 303.

7 Ibid., s. 302. 
W literaturze poświęconej Stanisławowi Staszicowi prawie nie zwraca się uwagi na analizę jego poglądów politycznych ostatniego okresu $1815-1826^{8}$. Tym bardziej nie można zgodzić się ze zdaniem, iż filozof był jednym z pierwszych przedstawicieli ruchu panslawistycznego w Polsce ${ }^{9}$, ponieważ w głównych swych założeniach zapatrywania Staszica wręcz przeciwstawiały się późniejszemu panslawizmowi jako ideologicznej modyfikacji oficjalnej rosyjskiej teorii narodowości.

Ttum. Agnieszka Babel

${ }^{8}$ Zob. np.: Z. Chyra-Rolicz, Stanistaw Staszic, Warszawa 1980; W. Hahn, Stanislaw Staszic, życie i dziela 1755-1826, Lublin 1926; C. Leśniewski, Stanistaw Staszic. Jego życie i ideologia, Warszawa 1925; J. Michalski, Z dziejów Towarzystwa Przyjaciót Nauk, Warszawa 1953; M. Reiter M., Stanistaw Staszic, Lwów 1905; Stanistaw Staszic. Ksiega zbiorowa, Lublin 1928.

${ }^{9}$ Zob. W. Hahn, op. cit., s. 79. 